\title{
In vivo roles of the germination-specific lytic enzymes of Bacillus subtilis 168
}

\author{
Abdelmadjid Atrih and Simon J. Foster \\ Author for correspondence: Simon J. Foster. Tel: +44 1142224411 . Fax: + 441142728697. \\ e-mail: s.foster@sheffield.ac.uk
}

Department of Molecular Biology and

Biotechnology, University of Sheffield, Firth Court, Western Bank, Sheffield S10 2TN, UK

\begin{abstract}
Germination of endospores of Bacillus subtilis involves the activities of several germination-specific lytic enzymes, including glucosaminidase and lytic transglycosylase. Another non-hydrolytic activity, likely to be due to an epimerase, also occurs. The effect of pH on enzyme activities and the overall germination rate was measured. Optimal germination occurred between pH 7-9; however, optimum glucosaminidase and epimerase activities were noted at pH 5. Conversely, the lytic transglycosylase activity was greatest at pH 8. Treatment of spores $(15 \mathrm{~min})$ with heat $\left(90^{\circ} \mathrm{C}\right)$ or $\mathrm{NaOH}(0.25 \mathrm{M})$ led to impaired cortex hydrolysis/modification, but with $<20 \%$ loss in viability. Analysis of muropeptides in the germination exudate revealed a reduction of $>85 \%$ in glucosaminidase and epimerase products, when compared to untreated spores. Conversely, lytic transglycosylase activity was increased by alkali or heat treatment, which was possibly due to increased substrate availability. FB101 (sleB) spores, which lack lytic transglycosylase activity, showed 90-fold greater loss in viability than the wild-type after $1 \mathrm{~h}$ at $90{ }^{\circ} \mathrm{C}$. Similarly, $97 \%$ of FB101 (s/eB) spores were unable to form a colony on nutrient agar after $130 \mathrm{~min}$ exposure to $0.25 \mathrm{M} \mathrm{NaOH}$ at $4{ }^{\circ} \mathrm{C}$, whereas the wild-type was unaffected. This demonstrates the crucial role of the lytic transglycosylase in cortex hydrolysis of damaged spores. The respective targets of heat and alkali in spores and their role during germination are discussed.
\end{abstract}

Keywords: spores, peptidoglycan, cortex, resistance, lytic transglycosylase

\section{INTRODUCTION}

Sporulation occurs in spore-forming bacteria in response to nutrient deprivation, resulting in the formation of spores with high levels of heat and chemical resistance (Nicholson et al., 2000; Warth, 1978). The thick sporespecific peptidoglycan layer, known as the spore cortex, is responsible for the maintenance of spore dormancy (Ellar, 1978; Gerhardt \& Marquis, 1989). The success of this survival mechanism lies in the retention of an efficient mechanism for returning the organism to the vegetative state, allowing outgrowth and multiplication when nutrients become available. Dormant spores of Bacillus subtilis respond to nutrient germinants, represented by L-alanine or a mixture of $\mathrm{L}$-asparagine, glucose, fructose and $\mathrm{KCl}$ (AGFK) (Wax \& Freese, 1968), or to non-nutrient germinants (as recently demonstrated by Paidhungat \& Setlow, 2000). The trigger

Abbreviations: AGFK, a mixture of L-asparagine, glucose, fructose and $\mathrm{KCl}$; $\mathrm{A}_{2} \mathrm{pm}$, diaminopimelic acid; GSLE, germination-specific lytic enzyme. reaction commits spores to undergo a series of degradative events, which result in the loss of spore dormancy and spore-resistance properties (Foster \& Johnstone, 1990). Hydrolysis of the spore cortex by germination-specific lytic enzymes (GSLEs) is considered a late event in germination (Atrih et al., 1998; Atrih \& Foster, 1999). However, it is essential for the removal of the physical constraint on the core so that outgrowth can occur (Atrih et al., 1998; Atrih \& Foster, 1999; Popham et al., 1996).

Recent findings have shown that cortex hydrolysis during germination is a complex process with at least three GSLEs involved: a glucosaminidase, a lytic transglycosylase and a possible amidase (Atrih et al., 1998, 1999; Atrih \& Foster, 1999; Boland et al., 2000). Another non-hydrolytic activity, suggested to be an epimerase, has also been noted (Atrih et al., 1998). Two components involved in cortex hydrolysis during $B$. subtilis germination have been identified. Spores of a sleB mutant germinate more slowly than the wild-type and analysis of peptidoglycan dynamics during germination has 

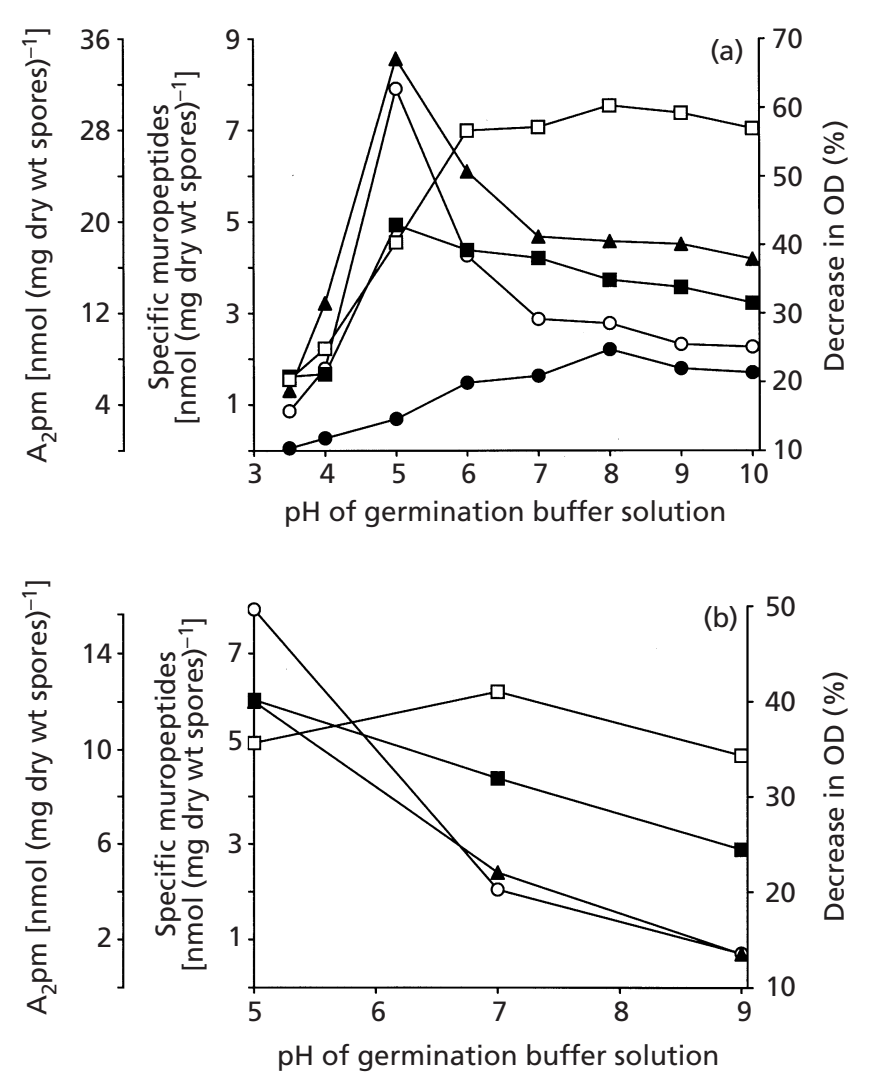

Fig. 1. Hydrolytic activity of GSLEs during germination of $B$. subtilis 168 spores at different pH values. (a) Strain HR (wildtype). (b) Strain FB101 (s/eB); lytic transglycolase activity is not shown as FB101 is deficient for this enzyme. $\square$, Germination of $B$. subtilis spores (percentage decrease in $\mathrm{OD}_{600}$ ); $O$, glucosaminidase products [nmol muropeptide (mg dry wt spores) ${ }^{-1}$ ]; 1 epimerase products [nmol muropeptide (mg dry wt spores) ${ }^{-1}$ ];, lytic transglycosylase products [nmol anhydromuropeptide (mg dry wt spores) ${ }^{-1}$; $\boldsymbol{\square}$, hydrolytic activity of GLSEs in terms of $A_{2} p m$ released into the exudate. Muropeptides and $A_{2} p m$ were quantified in germination exudates.

revealed that the gene is likely to encode a lytic transglycosylase (Boland et al., 2000). The cwlJ gene product is homologous to SleB (Ishikawa et al., 1998). A cwlJ mutation results in slower germination and a sleB/cwlJ double mutant cannot hydrolyse the cortex during germination (Ishikawa et al., 1998).

A number of GSLEs have been purified from germinated or broken spores of Bacillus megaterium, Bacillus cereus and Clostridium perfringens (Chen et al., 1997, 2000; Foster \& Johnstone, 1987; Makino et al., 1994; Miyata et al., 1995; Moriyama et al., 1996). The common property shared by these GSLEs is the requirement for the presence of the muramic $\delta$-lactam moiety on the spore cortex for activity. Purified GSLEs extracted from spores are not unusually heat resistant (Chen et al., 1997, 2000; Foster \& Johnstone, 1987; Moriyama et al., 1996; Warth, 1978); therefore they must be protected against heat within the internal environment of spores. Unfortunately in B. subtilis, attempts to isolate active
GSLEs from germinated or physically broken spores have been unsuccessful (T. J. Smith \& S. J. Foster, unpublished). In C. perfringens heat and $\mathrm{NaOH}$ inactivate GSLEs involved in cortex hydrolysis, since treated spores can be partially rescued by lysozyme (Duncan et al., 1972; Labbe \& Chang, 1995). However, the role of the multiple GSLEs of B. subtilis and their potential as sporicidal targets is still unknown. In this study we have analysed the combined function of the GSLEs of B. subtilis in germination under different environmental conditions and in response to sporicidal treatments.

\section{METHODS}

Preparation and germination of spores. Spores of B. subtilis HR (wild-type) and B. subtilis FB101 (sleB; Boland et al., 2000) were prepared in CCY medium, washed, and stored as previously described (Atrih et al., 1996, 1998).

Germination of spores at different $\mathbf{p H}$ values. Washed spores of strain HR and strain FB101 were suspended at a final concentration of $3 \mathrm{mg}$ dry $\mathrm{wt} \mathrm{ml}^{-1}$ in distilled water, and heatshocked at $70{ }^{\circ} \mathrm{C}$ for $30 \mathrm{~min}$. Spores were then cooled on ice and used within $1 \mathrm{~h}$ (Atrih et al., 1998). The following germination buffer solutions were used at a final concentration of $20 \mathrm{mM}$ in the presence of $20 \mathrm{mM} \mathrm{KCl}$ : sodium acetate/ acetic acid ( $\mathrm{pH} 3 \cdot 5-5)$, potassium phosphate buffer ( $\mathrm{pH} 5-7$ ), and Tris/ $\mathrm{HCl}$ buffer $(\mathrm{pH} 8-10)$. Germination was triggered by L-alanine $(1 \mathrm{mM}$; a saturating concentration for germination) and monitored by recording the decrease of $\mathrm{OD}_{600}$ as previously described (Atrih et al., 1998). After $2 \mathrm{~h}$, germination exudates were collected by centrifugation $\left(14000 \mathrm{~g}, 8 \mathrm{~min}, 4^{\circ} \mathrm{C}\right.$ ), boiled for $3 \mathrm{~min}$ and the $\mathrm{pH}$ was adjusted to 5 before lyophilization. Germination was carried out for $2 \mathrm{~h}$, a time at which $>90 \%$ of total $\mathrm{OD}_{600}$ loss had occurred. All germination experiments were repeated at least twice and showed less than $10 \%$ variation.

Spore heat treatment. Spores were suspended at a final concentration of $3 \mathrm{mg}$ dry $\mathrm{wt} \mathrm{m}^{-1}$ in distilled water and heattreated at $90^{\circ} \mathrm{C}$ for different times. The heat-treated spores were immediately cooled on ice and used for germination experiments within $1 \mathrm{~h}$, without further heat shock.

Spore alkali treatment. Spores $\left(4 \mathrm{mg}\right.$ dry weight $\mathrm{ml}^{-1}$ ) were suspended in distilled water (on ice), and $\mathrm{NaOH}$ was added to give a final concentration of $0.25 \mathrm{M}$. After treatment the spores were recovered by centrifugation $\left(12000 \mathrm{~g}, 8 \mathrm{~min}, 4^{\circ} \mathrm{C}\right)$ and washed three times by centrifugation and resuspension with $20 \mathrm{mM}$ phosphate buffer at $\mathrm{pH} 6$, then twice with distilled water at $4{ }^{\circ} \mathrm{C}$. Spores were heat shocked at $65^{\circ} \mathrm{C}$ for $25 \mathrm{~min}$ and germination was then performed as indicated above.

Lysozyme recovery of heat- or alkali-treated spores. Lysozyme was added to molten nutrient agar $\left(48^{\circ} \mathrm{C}\right)$ to give a final concentration of $0 \cdot 15,0 \cdot 3,0.6$ and $1.0 \mu \mathrm{g} \mathrm{ml}^{-1}$ prior to pouring the plates. The experiments were performed in duplicate and plate counts were determined after $48 \mathrm{~h}$. The lysozyme concentrations used in this study do not affect the total viable count of HR untreated spores.

Muropeptide purification and amino acid analysis. Muropeptide purification and quantification in the germination exudate were performed as previously described (Atrih et al., 1996, 1998). Diaminopimelic acid $\left(\mathrm{A}_{2} \mathrm{pm}\right)$, a peptidoglycanspecific amino acid, was used to measure the amount of peptidoglycan released in the exudate by the Pico-Tag method 


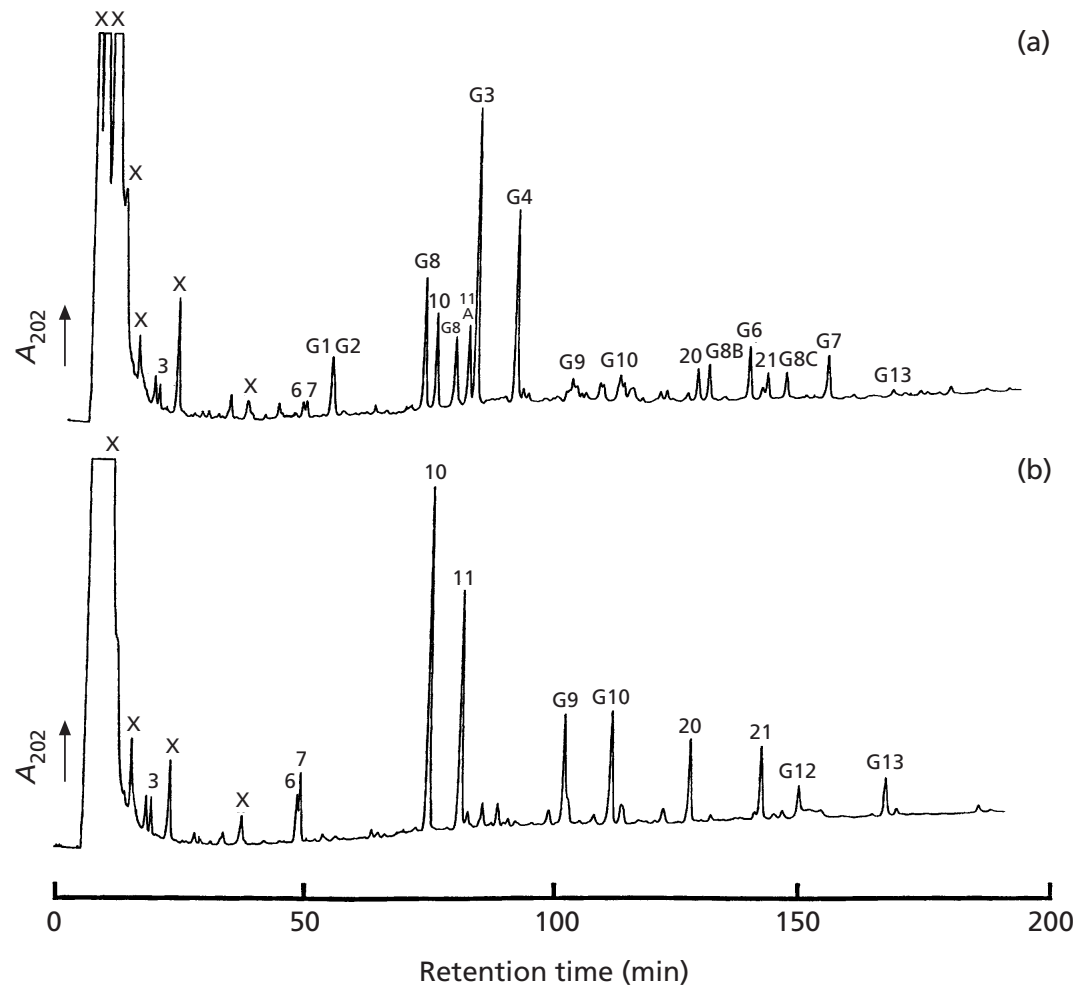

Fig. 2. Analysis of muropeptides by reversephase HPLC. Muropeptide-containing samples of germination exudate $(2 \mathrm{~h})$ from an equivalent amount of dry weight of (a) B. subtilis untreated spores, and (b) B. subtilis heat-treated spores $\left(90^{\circ} \mathrm{C}\right.$ for $1 \mathrm{~h})$ were digested with Cellosyl and the resulting muropeptides were separated by HPLC. After this heat treatment $8 \%$ of the spores retained viability. The numbered muropeptides are products of the following enzymes: G1-G7, likely epimerase activity (Atrih et al., 1998); G8, G8A, G8B and G8C, glucosaminidase (Atrih et al., 1998; Boland et al., 2000); G9, G10, G12 and G13, lytic transglycolase (Atrih et al., 1998). X peaks represent non-peptidoglycan-derived products.

(Atrih et al., 1996, 1998). All experiments were carried out in duplicate. The results shown are representative; there was $<5 \%$ variability between experiments.

\section{RESULTS}

\section{Effect of $\mathrm{pH}$ on germination}

Heat shocked spores were germinated over a $\mathrm{pH}$ range of 3.5 to 10 . Optimal germination $(57-60 \%$ drop in $\mathrm{OD}_{600}$ readings) occurred at $\mathrm{pH} 6-10$, with a sharp decline to only a $23 \%$ loss in the $\mathrm{OD}_{600}$ value at $\mathrm{pH} 3.5$ (Fig. 1a). Microscopic analysis (phase contrast) showed that at $\mathrm{pH} 3.5$ only a small proportion of the spore population had germinated (results not shown). Glucosaminidase and lytic transglycosylase activities during germination result in products which appear in significant quantities in only the germination exudate (Atrih et al., 1998). Epimerase products are present in roughly equal amounts in the exudate and the sporeassociated material. Alteration in spore-associated epimerase products matched that in the exudate under all treatments used in this study (results not shown). Analysis of exudates from spores germinated at different $\mathrm{pH}$ values $\left(2 \mathrm{~h}, 37^{\circ} \mathrm{C}\right)$ revealed the pattern of enzyme activities involved in cortex hydrolysis and modification. Enzyme activities were measured by the amount of products generated. Fig. 1(a) shows that glucosaminidase and epimerase products were maximal at pH $5[7.9 \mathrm{nmol}$ and $8.5 \mathrm{nmol}$ muropeptides (mg dry wt spores $)^{-1}$ after $2 \mathrm{~h}$, respectively]. The highest activities of these enzymes at $\mathrm{pH} 5$ were apparent in both acetate and phosphate buffers (results not shown). Conversely, lytic transglycosylase was less active at acidic $\mathrm{pH}$. It was maximal at $\mathrm{pH} 8$, generating a total of $2 \cdot 2 \mathrm{nmol}$ anhydro-muropeptides (mg dry wt spores) ${ }^{-1}$ (Fig. 1a). GSLE hydrolytic activities resulted in fragments of peptidoglycan released into the exudate, which could be assayed as $\mathrm{A}_{2} \mathrm{pm}$. Optimal GLSE hydrolytic activities [19.7 nmol $\mathrm{A}_{2} \mathrm{pm}$ (mg dry wt spores) ${ }^{-1}$ ] occurred at $\mathrm{pH} 5$ after $2 \mathrm{~h}$ germination.

\section{Germination of heat-treated spores}

Heat treatment of spores at $90{ }^{\circ} \mathrm{C}$ for $130 \mathrm{~min}$ did not affect the dormant spore muropeptide profile, and the spores remained phase bright (results not shown). However, it did result in a loss of approximately $20 \%$ of the initial $\mathrm{OD}_{600}$ of the dormant spore suspension (results not shown). After germination of the heattreated spores $>90 \%$ became phase dark. The reversephase HPLC profile of muropeptides in the germination exudate of untreated and heat-treated spores $\left(90^{\circ} \mathrm{C}\right.$ for $1 \mathrm{~h})$ germinated at $\mathrm{pH} 5$ for $2 \mathrm{~h}$ is shown in Fig. 2. Surprisingly, germinated heat-treated spores demonstrated a complete absence of the muropeptides generated by glucosaminidase (G8, G8A, G8B and G8C; Atrih et al., 1998; Boland et al., 2000) and likely epimerase activity (G1-G7; Atrih et al., 1998). Germinated heat-treated spores also showed an increase in muropeptides generated by lytic transglycosylase activity (G9, G10, G12 and G13; Atrih et al., 1998).

To examine the relative heat sensitivity of peptidoglycan hydrolytic and modification activities, spores were heat treated at $90^{\circ} \mathrm{C}$ for 15,30 and $60 \mathrm{~min}$ and then germinated at $\mathrm{pH} 5$ for $2 \mathrm{~h}$ prior to muropeptide analysis. Quantification of the enzyme products revealed 

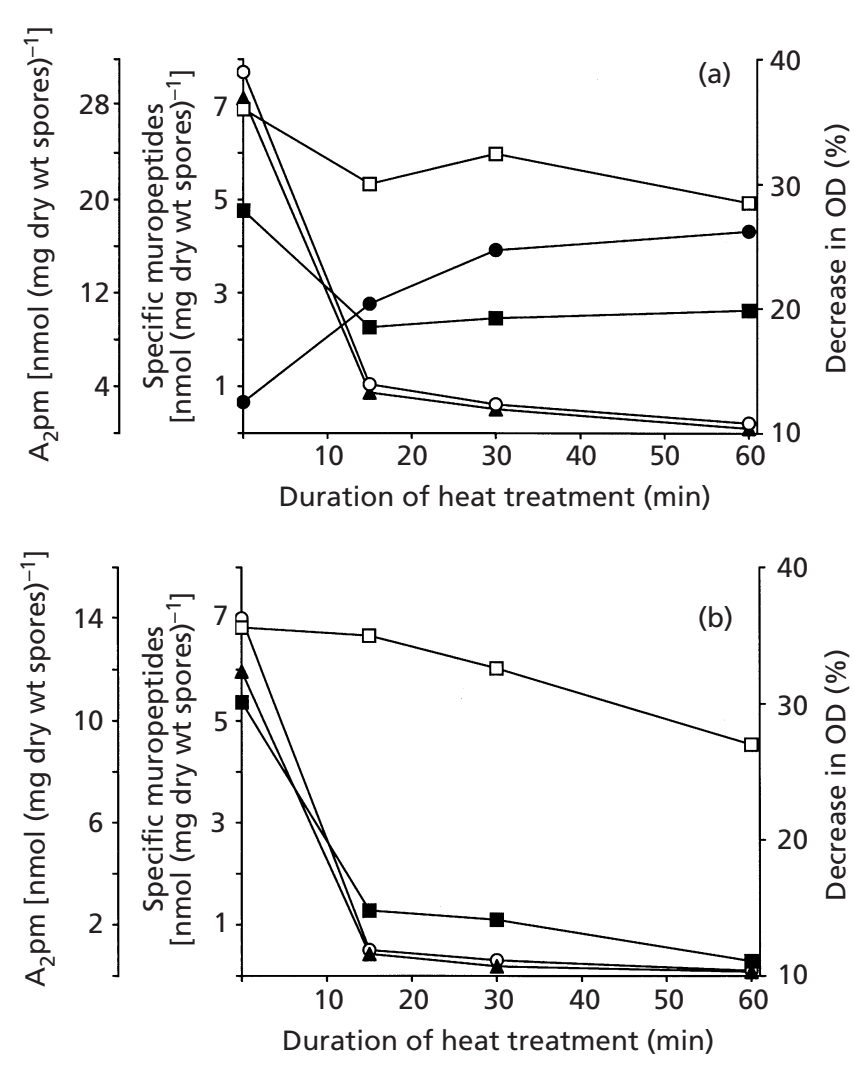

Fig. 3. GSLE activity during germination of $B$. subtilis heattreated spores at pH 5. (a) Strain HR (wild-type). (b) Strain FB101 $(s / e B) . \square$, Germination of $B$. subtilis spores expressed in terms of the percent decrease in $\mathrm{OD}_{600}$ readings; $O$, glucosaminidase products [nmol muropeptide (mg dry wt spores) ${ }^{-1}$ ]; epimerase products [nmol muropeptide (mg dry wt spores) ${ }^{-1}$ ]; - lytic transglycosylase products [nmol anhydro-muropeptide (mg dry wt spores) ${ }^{-1}$ ]; $\boldsymbol{\square}$, hydrolytic activity of GSLEs in terms of $\mathrm{A}_{2} \mathrm{pm}$ [nmol $\mathrm{A}_{2} \mathrm{pm}$ (mg dry wt spores) ${ }^{-1}$ ]. Muropeptides and $\mathrm{A}_{2} \mathrm{pm}$ were quantified in germination exudates.

that $88 \%$ and $87 \%$, respectively, of glucosaminidase and epimerase products disappeared within $15 \mathrm{~min}$ heat treatment at $90^{\circ} \mathrm{C}$ (Fig. 3a). Conversely, lytic transglycosylase activity increased after heat treatment. Indeed, after $1 \mathrm{~h}$ treatment at $90{ }^{\circ} \mathrm{C}$ the total amount of lytic transglycosylase products was $6 \cdot 6$-fold more than that in untreated spores (Fig. 3a). Quantification of $\mathrm{A}_{2} \mathrm{pm}$ in the exudate of $1 \mathrm{~h}$ heat-treated spores revealed that even after prolonged heat treatment, $45 \%$ of the material was still released compared to the control (Fig. 3a).

Germination and cortex hydrolysis/modification capabilities of heat-treated spores were also examined at $\mathrm{pH}$ 7. After 15 min heat treatment at $90{ }^{\circ} \mathrm{C}$, germination exudate ( $2 \mathrm{~h}$ germinated spores at $\mathrm{pH} 7$ ) was completely devoid of glucosaminidase and epimerase products (results not shown). Lytic transglycosylase was, however, more active at $\mathrm{pH} 7$ than $\mathrm{pH} 5$ as evidenced by a $12 \%$ increase in the amount of anhydro-muropeptides found in the exudate of $1 \mathrm{~h}$ heat-treated spores (results not shown).

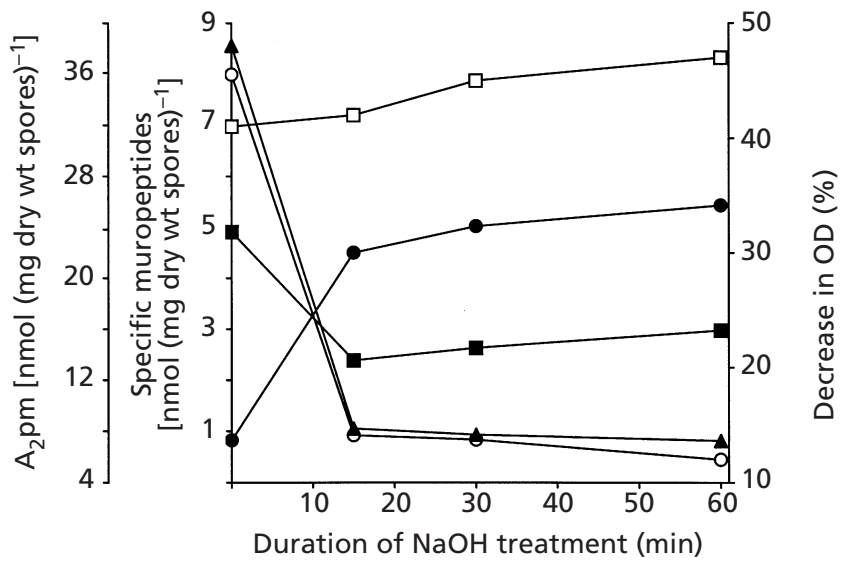

Fig. 4. GSLE activity during germination of $B$. subtilis $H R$ alkalitreated spores at $\mathrm{pH} 5 . \square$, Germination of $B$. subtilis spores expressed in terms of the percent decrease in $O_{600}$ readings; $O$, glucosaminidase products [ $\mathrm{nmol}$ muropeptide $(\mathrm{mg}$ dry wt spores) ${ }^{-1}$ ]; $\boldsymbol{\Lambda}$, epimerase products [nmol muropeptide (mg dry wt spores) ${ }^{-1}$ ]; 0 , lytic transglycosylase products [nmol anhydro-muropeptide (mg dry wt spores) $\left.{ }^{-1}\right] ; \mathbf{\square}$, hydrolytic activity of GSLEs in terms of $A_{2} p m$ [nmol $A_{2} p m$ (mg dry wt spores) ${ }^{-1}$ ]. Muropeptides and $\mathrm{A}_{2} \mathrm{pm}$ were quantified in germination exudates.

\section{Germination of alkali-treated spores}

Treatment of dormant B. subtilis HR spores with $0 \cdot 25 \mathrm{M}$ $\mathrm{NaOH}$ for $130 \mathrm{~min}$ did not affect the peptidoglycan structure significantly, although a minor change of a $1.5 \%$ increase of muropeptides with an open lactam was noted (results not shown) (Atrih et al., 1996). Alkalitreated spores were evaluated for their germination ability and cortex hydrolysis. The loss of $\mathrm{OD}_{600}$ during germination actually increased after $1 \mathrm{~h}$ in $0.25 \mathrm{M}$ $\mathrm{NaOH}$ treatment, from $41 \%$ (untreated) to $47 \%$, a slight but reproducible effect (Fig. 4). The loss of epimerase and glucosaminidase products in alkalitreated spores followed a similar pattern to heat-treated spores: $88 \%$ and $89 \%$ of epimerase and glucosaminidase products, respectively, were lost within 15 min (Fig. 4). Lytic transglycosylase activity was not only alkali resistant, but actually increased after treatment (Fig. 4). The amount of $\mathrm{A}_{2} \mathrm{pm}$ released from $1 \mathrm{~h}$ alkali-treated spores was $40 \%$ lower than that released from untreated spores. Heat- and alkali-treated spores were also germinated in the presence of AGFK and similar results to those obtained with L-alanine were noted (results not shown).

\section{Germination of sleB mutant spores}

Spores of B. subtilis FB101 (sleB) have a defect in cortex hydrolysis during germination, due to the lack of the lytic transglycosylase activity (Boland et al., 2000). Fig. 1 (b) shows that the optimum loss of $\mathrm{OD}_{600}$ during germination occurred at $\mathrm{pH} 7$, whereas release of peptidoglycan material was greatest at pH 5 (Fig. 1b). As expected, both glucosaminidase and epimerase ac- 


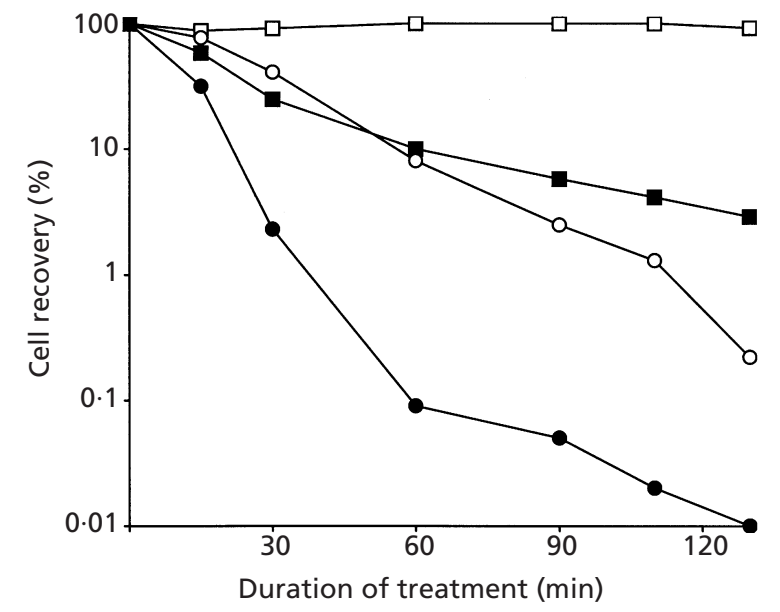

Fig. 5. Effect of heat or alkali treatment on dormant spore viability of $B$. subtilis $\mathrm{HR}$ and $B$. subtilis FB101 (sleB). The symbols used represent: $O, B$. subtilis HR heat-treated at $90{ }^{\circ} \mathrm{C}$; $\square$, B. subtilis HR alkali-treated with $0.25 \mathrm{M} \mathrm{NaOH} ; 0, B$. subtilis FB101 heat-treated at $90^{\circ} \mathrm{C} ; \mathbf{\square}, B$. subtilis FB101 alkali-treated with $0.25 \mathrm{M} \mathrm{NaOH}$. Cell recovery was calculated using the equation (treated c.f.u. $\mathrm{ml}^{-1} /$ untreated c.f.u. $\mathrm{ml}^{-1}$ ) $\times 100$, and expressed as percentage values.

tivities are maximal at $\mathrm{pH}$ 5. Under no conditions was any lytic transglycosylase activity observed. Heattreated spores of FB101 (sleB) were dramatically affected in germination and cortex hydrolysis. After $1 \mathrm{~h}$ treatment at $90{ }^{\circ} \mathrm{C}$, glucosaminidase and epimerase were scarcely detected after germination at $\mathrm{pH} 5$ for $2 \mathrm{~h}$ (Fig. $3 \mathrm{~b})$. The release of $\mathrm{A}_{2} \mathrm{pm}$ into the exudate also decreased dramatically, with only $6 \%$ of the value of the untreated sample released (Fig. 3b). FB101 (sleB) alkali-treated spores also showed a similar pattern in GSLE inactivation (results not shown).

\section{Effect of heat or $\mathrm{NaOH}$ on spore survival}

As GSLEs are crucial enzymes in cortex hydrolysis their inactivation, by heat or $\mathrm{NaOH}$, may affect spore survival. Heat treatment $\left(90^{\circ} \mathrm{C}\right)$ of $B$. subtilis $\mathrm{HR}$ spores led to a decline in viable cell numbers (as measured by c.f.u.) resulting in only $0 \cdot 2 \%$ recovery after $130 \mathrm{~min}$ treatment. Spores of FB101 (sleB) were considerably more heat sensitive, with only $0.01 \%$ recovery after $130 \mathrm{~min}$ heat treatment (Fig. 5). Wild-type spores of B. subtilis were not affected by alkali treatment $(0 \cdot 25 \mathrm{M})$ for up to $130 \mathrm{~min}$ (Fig. 5). However, the lack of SleB in strain FB101 resulted in sensitivity to alkali. Indeed, $97 \%$ of spores had lost viability within the $130 \mathrm{~min}$ treatment (Fig. 5).

\section{Lysozyme recovery of heat- and alkali-treated spores}

If cortex lytic enzymes are damaged during treatment, spores may not be able to outgrow and divide to form a colony on nutrient agar. Exogenous lysozyme can substitute for endogenous enzymes and may allow recovery to occur (Duncan et al., 1972; Labbe \& Chang, 1995). Lysozyme has no effect on the colony-forming ability of HR (wild-type) spores with or without heat treatment (results not shown). Unexpectedly, lysozyme resulted in a reproducible $1 \cdot 5$-fold increase in recovery of even untreated spores of FB101 (sleB) (Table 1). Indeed our results suggest on average $33 \%$ of sleB spores were unable to form colonies on nutrient agar plates (Table 1). Lysozyme treatment of FB101 (sleB) resulted in comparable c.f.u. per unit $\mathrm{OD}_{600}$ as wild-type (results not shown). Lysozyme was also able to recover FB101 strain $($ sleB) spores after heat and $\mathrm{NaOH}$ treatment. This recovery was lysozyme concentration dependent. Treatment with $1 \mu \mathrm{g}$ lysozyme $\mathrm{ml}^{-1}$ resulted in a fiveand tenfold increase in recovery after heat or $\mathrm{NaOH}$ treatment for $60 \mathrm{~min}$ and $130 \mathrm{~min}$, respectively.

Table 1. Effect of lysozyme on recovery of untreated, and heat- or alkali-treated spores of FB101 (sleB)

All spores were treated at $\mathrm{OD}_{600} 2 \cdot 5$. The results are the mean of two experiments with two different preparations of spores, which showed less than twofold variability between each run.

\begin{tabular}{|c|c|c|c|c|c|}
\hline \multirow[t]{2}{*}{$\begin{array}{l}\text { Lysozyme concn } \\
\left(\mu \mathrm{g} \mathrm{ml}^{-1}\right)\end{array}$} & \multirow[t]{2}{*}{$\begin{array}{l}\text { c.f.u. } \mathrm{ml}^{-1} \text { for } \\
\text { untreated spores }\end{array}$} & \multicolumn{2}{|c|}{$\begin{array}{l}\text { Heat-treated spores } \\
\qquad\left(90{ }^{\circ} \mathrm{C}, 60 \mathrm{~min}\right)\end{array}$} & \multicolumn{2}{|c|}{$\begin{array}{l}\text { Alkali-treated spores } \\
(0.25 \mathrm{M}, 130 \mathrm{~min})\end{array}$} \\
\hline & & c.f.u. $\mathrm{ml}^{-1}$ & $\begin{array}{c}\text { Recovery } \\
(\%)^{*}\end{array}$ & c.f.u. $\mathrm{ml}^{-1}$ & $\begin{array}{c}\text { Recovery } \\
(\%)^{*}\end{array}$ \\
\hline $0 \cdot 00$ & $8.7 \times 10^{6}$ & $8 \cdot 0 \times 10^{3}$ & $0 \cdot 10$ & $3 \cdot 0 \times 10^{5}$ & $3 \cdot 45$ \\
\hline $0 \cdot 15$ & $1 \cdot 1 \times 10^{7}$ & $4 \cdot 0 \times 10^{4}$ & $0 \cdot 36$ & $3 \cdot 0 \times 10^{6}$ & $27 \cdot 27$ \\
\hline $0 \cdot 30$ & $1 \cdot 2 \times 10^{7}$ & $5 \cdot 0 \times 10^{4}$ & $0 \cdot 42$ & $3 \cdot 5 \times 10^{6}$ & $29 \cdot 17$ \\
\hline $0 \cdot 60$ & $1 \cdot 3 \times 10^{7}$ & $5 \cdot 6 \times 10^{4}$ & $0 \cdot 43$ & $3 \cdot 9 \times 10^{6}$ & $30 \cdot 00$ \\
\hline $1 \cdot 00$ & $1 \cdot 3 \times 10^{7}$ & $6.5 \times 10^{4}$ & $0 \cdot 50$ & $4.8 \times 10^{6}$ & $36 \cdot 92$ \\
\hline
\end{tabular}

* Determined from viable counts obtained after incubation of plates at $37^{\circ} \mathrm{C}$ for $48 \mathrm{~h}$. Counts obtained for untreated spores at each lysozyme concentration were considered as $100 \%$ recovery. Percentage recovery for heat- or alkali-treated samples was calculated for each lysozyme concentration, using the equation (treated c.f.u. $\mathrm{ml}^{-1} /$ untreated c.f.u. $\mathrm{ml}^{-1}$ ) $\times 100$. 


\section{DISCUSSION}

Cortex hydrolysis of B. subtilis spores is complex and at least three enzyme activities are involved in germination (Atrih et al., 1998): glucosaminidase, lytic transglycosylase and non-hydrolytic, likely epimerase, activities. The individual roles of the enzymes responsible for the observed activities are unknown. In order to unravel the complex interrelationship between the enzymes, the effects of germination conditions and sporicidal treatments were assessed in vivo.

Glucosaminidase activity has been previously reported to have a minor role in cortex hydrolysis at $\mathrm{pH} 7$ (Atrih et al., 1998). Here we have shown that glucosaminidase activity is optimum at $\mathrm{pH} 5$. Germination at $\mathrm{pH} 5$ also resulted in a maximal release of peptidoglycan fragments as shown by the amount of $\mathrm{A}_{2} \mathrm{pm}$ in the exudate. This is in contrast with the lower loss of $\mathrm{OD}_{600}$ compared to spores germinated at $\mathrm{pH} 7-10$. The loss of $\mathrm{OD}_{600}$ has already been shown to occur in spores without any cortex hydrolysis (Atrih et al., 1998; Popham et al., 1996; Sekiguchi et al., 1995). Therefore, it is likely to be due to the loss of other spore components such as dipicolinic acid, and the uptake of water (Atrih \& Foster, 1999; Sekiguchi et al., 1995). The effect of $\mathrm{pH}$ on germination of $B$. megaterium and B. subtilis has been previously investigated (Ciarciaglini et al., 2000; Stewart et al., 1981). In both organisms optimum absorbance loss occurs at slightly basic $\mathrm{pH} 7-9$, which correlates with our results.

Another important feature of B. subtilis GSLEs is their activities over a $\mathrm{pH}$ range of $4-10$. These observations concur with previous reports on various purified GSLEs from other spore-forming bacteria (Chen et al., 1997, 2000; Makino et al., 1994). The differential activities of the GSLEs at different $\mathrm{pH}$ values may be important in underlining their potential role in spore germination in diverse environments.

GSLEs isolated from spore-forming bacteria are not unusually heat resistant and are generally denatured at temperatures lower than those required in inactivating whole spores (Chen et al., 2000; Makino et al., 1994). The extensive studies of Warth (1980) also indicate that enzymes of central metabolism are inactivated at temperatures $24-46{ }^{\circ} \mathrm{C}$ lower than those required to inactivate the same enzymes within intact spores.

Heat or alkali treatment of $B$. subtilis spores resulted in rapid loss of epimerase and glucosaminidase activities. These results suggest that the enzymes themselves, or their activation mechanism(s), are sensitive to heat and alkali. The fact that the two distinct treatments affect the same enzymes suggests that the localization or the mechanisms of activation of these enzymes are different to that of the lytic transglycosylase. The $\mathrm{NaOH}$ effect implies a close association or location of some germination components with the alkali-soluble proteins, which are removed by such treatment (Duncan et al., 1972; Gould et al., 1970). The lytic transglycosylase is not affected by heat or $\mathrm{NaOH}$ and thus this enzyme is protected to a much greater degree than the other enzymes. Alternatively, the glucosaminidase and epimerase may be protected, but their activation mechanism(s) is not.

In B. subtilis, sleB and the adjacent downstream $y p e B$ gene form a bicistronic operon (Moriyama et al., 1999), and both genes are necessary for cortex hydrolysis (Boland et al., 2000). SleB is most likely a lytic transglycosylase (Boland et al., 2000) and is located in a mature form on the outside of the cortex in the dormant spore (Moriyama et al., 1999). This localization of the enzyme does not correlate with its exceptional resistance to heat and alkali, suggesting that it may have a unique protection mechanism. Studies using FB101 (sleB) highlight the $\mathrm{pH}$ dependence of germination enzyme activities. In FB101 (sleB) the maximal release of peptidoglycan material during germination occurred at $\mathrm{pH} 5$, the $\mathrm{pH}$ at which glucosaminidase activity is greatest. The role of the likely epimerase in cortex hydrolysis is not clear, as it is not a hydrolytic enzyme. However, it has been previously suggested to cause an alteration in peptidoglycan conformation which may affect the activity of the GSLEs (Atrih et al., 1998). The present study suggests that the epimerase is not necessary for cortex hydrolysis since the lytic transglycosylase is active in the absence of significant epimerase activity.

CwlJ is another apparent GSLE involved in cortex hydrolysis (Ishikawa et al., 1998). The hydrolytic bondspecificity of this enzyme is still unknown and the double mutant sleB/cwlJ is unable to hydrolyse the cortex as evidenced by the absence of peptidoglycan fragments in the germination exudate (Ishikawa et al., 1998). Thus, the epimerase and glucosaminidase activities are unable to initiate cortex hydrolysis. Also, CwlJ activity or its activation mechanism must be destroyed by heating, as FB101 (sleB) spores show reduced heat resistance compared to the parent. The lytic transglycosylase is probably the only significant enzyme which survives heat treatment and is able to hydrolyse the cortical peptidoglycan to allow outgrowth. The heat sensitivity of FB101 (sleB) spores is not due to the core dehydration level, as the core wet density of the mutant is comparable to that of wild-type spores (results not shown).

From previous work it was not apparent whether the products of glucosaminidase or lytic transglycosylase activities are acted on by the epimerase (Atrih et al., 1998). In this study, the lytic transglycosylase products are not altered by epimerase because their retention time is identical in the presence or absence of epimerase. Similarly, partially purified glucosaminidase from $B$. megaterium generated products with identical retention time to those obtained in the presence of epimerase (Atrih et al., 1999). It is possible that epimerase products are resistant to the action of other enzymes, and that the subtle modification of the peptidoglycan may direct hydrolysis to optimize the hydrolytic effect of the other GSLEs. Thus, the increase in lytic transglycosylase activity in both the heat- and alkali-treated spores could 
be explained by the availability of substrate in the absence of the other enzymes.

The loss of spore viability during heat treatment cannot be correlated directly with GSLE activities. Indeed, after $1 \mathrm{~h}$ treatment of spores at $90{ }^{\circ} \mathrm{C}$ only $8 \%$ of spores remained viable but the lytic transglycosylase was still fully active. Thus, even though cortex hydrolysis is taking place in this case, it is likely that outgrowth or vegetative growth components have been damaged, thus preventing colony formation. This is confirmed by the inability of lysozyme to recover heat-treated spores of C. perfringens (Duncan et al., 1972; Labbe \& Chang, 1995). Enzymes and other proteins are the main targets for heat-killing of spores (Belliveau et al., 1992; Marquis et al., 1994; Nicholson et al., 2000); however, it is still unclear which proteins are the critical targets for such treatment (Nicholson et al., 2000).

Alkali treatment of spores, although it affects glucosaminidase and epimerase activities, does not affect spore viability. Also, CwlJ activity must be inactivated by alkali as sleB spores are much more sensitive than the wild-type to this treatment. Thus, the glucosaminidase, epimerase and CwlJ activities are not crucial for germination in alkali-treated spores; however SleB certainly is. In C. perfringens both heat and alkali treatment reduced the apparent viability of spores to a comparable level (Duncan et al., 1972). Furthermore, the loss of viability in alkali-treated spores was linked to inactivation of GSLEs. This implies that although the bacterial spores share a conserved peptidoglycan structure, the GSLEs involved in its hydrolysis show some diversity (Atrih \& Foster, 1999, 2001; Foster \& Johnstone, 1988; Moriyama et al., 1999).

Previous studies have shown that heat combined with additional controlling factors $(\mathrm{pH}$, organic acids, preservatives) affects Bacillus species spore viability (Oloyede \& Scholefield, 1994), outgrowth and germination (Ciarciaglini et al., 2000). However, none of these studies identified the molecular target of the treatments. Here we have shown that the major GSLE, SleB, is a critical resistance determinant for $B$. subtilis spores in response to heat, and in particular $\mathrm{NaOH}$. Thus, development of inhibitors of GSLEs coupled with sporicidal treatments may provide novel combinatorial approaches to prevent outgrowth of potentially deleterious spore-formers. It is by a further understanding of the molecular mechanisms of spore germination and resistance that rational spore control measures can be developed.

\section{ACKNOWLEDGEMENTS}

This work was supported by the BBSRC (A.A.) and the Royal Society (S. J.F.).

\section{REFERENCES}

Atrih, A. \& Foster, S. J. (1999). The role of peptidoglycan structure and structural dynamics during endospore dormancy and germination. Antonie Leeuwenhoek 75, 299-307.

Atrih, A. \& Foster, S. J. (2001). Analysis of the role of bacterial endospore cortex structure in resistance properties and dem- onstration of its conservation amongst species. J Appl Microbiol 91, 1-9.

Atrih, A., Zöllner, P., Allmaier, G. \& Foster, S. J. (1996). Structural analysis of Bacillus subtilis 168 endospore peptidoglycan and its role during differentiation. J Bacteriol 178, 6173-6183.

Atrih, A., Zöllner, P., Allmaier, G., Williamson, M. P. \& Foster, S. J. (1998). Peptidoglycan structural dynamics during germination of Bacillus subtilis 168 endospores. J Bacteriol 180, 4603-4612.

Atrih, A., Bacher, G., Körner, R., Allmaier, G. \& Foster, S. J. (1999). Structural analysis of Bacillus megaterium KM spore peptidoglycan and its dynamics during germination. Microbiology 145, 1033-1041.

Belliveau, B. H., Beaman, T. C., Pankratz, S. \& Gerhardt, P. (1992). Heat killing of bacterial spores analysed by differential scanning calorimetry. J Bacteriol 174, 4463-4474.

Boland, F. M., Atrih, A., Chirakkal, H., Foster, S. J. \& Moir, A. (2000). Complete spore cortex hydrolysis during germination of Bacillus subtilis 168 requires SleB and YpeB. Microbiology 146, 57-64.

Chen, Y., Miyata, S., Makino, S. \& Moriyama, R. (1997). Molecular characterization of a germination-specific muramidase from Clostridium perfringens S40 spores and nucleotide sequence of the corresponding gene. J Bacteriol 179, 3181-3187.

Chen, Y., Fukuoka, S. \& Makino, S. (2000). A novel spore peptidoglycan hydrolase of Bacillus cereus, biochemical characterization and nucleotide sequence of the corresponding gene, sleL. J Bacteriol 182, 1499-1506.

Ciarciaglini, G., Hill, P. J., Davies, K., MacClure, P. J., Kilsby, D., Brown, M. H. \& Coote, P. J. (2000). Germination-induced bioluminescence, a route to determine the inhibitory effect of a combination preservation treatment on bacterial spores. Appl Environ Microbiol 66, 3735-3742.

Duncan, C. L., Labbe, R. G. \& Reich, R. R. (1972). Germination of heat- and alkali-altered spores of Clostridium perfringens type A by lysozyme and an initiation protein. J Bacteriol 109, 550-559.

Ellar, D. J. (1978). Spore specific structures and their functions. In Relations between Structure and Function in the Prokaryotic Cell (Society for General Microbiology Symposium no. 28), pp. 295-325. Edited by R. Y. Stanier, H. J. Rogers \& J. B. Ward. Cambridge: Cambridge University Press.

Foster, S. J. \& Johnstone, K. (1987). Purification and properties of a germination-specific cortex lytic enzyme from spores of Bacillus megaterium KM. Biochem J 242, 573-579.

Foster, S. J. \& Johnstone, K. (1988). Germination-specific cortexlytic enzyme is activated during triggering of Bacillus megaterium KM spore germination. Mol Microbiol 2, 727-733.

Foster, S. J. \& Johnstone, K. (1990). Pulling the trigger, the mechanism of bacterial spore germination. Mol Microbiol 4, 137-141.

Gerhardt, P. \& Marquis, R. E. (1989). Spore thermoresistance mechanisms. In Regulation of Procaryotic Development, pp. 43-63. Edited by I. Smith, R. Slepecky \& P. Setlow. Washington, DC: American Society for Microbiology.

Gould, G. W., Stubbs, J. M. \& King, W. L. (1970). Structure composition and resistant layers in bacterial spore coats. J Gen Microbiol 60, 347-355.

Ishikawa, S., Yamane, K. \& Sekiguchi, J. (1998). Regulation and characterization of a newly deduced cell wall hydrolase gene $(c w l J)$ which affects germination of Bacillus subtilis spores. J Bacteriol 180, 1375-1380.

Labbe, R. G. \& Chang, C. A. (1995). Recovery of heat-injured 
spores of Clostridium perfringens type B, C and D by lysozyme and an initiation protein. Lett Appl Microbiol 21, 302-306.

Makino, S., Ito, N., Inoue, T., Miyata, S. \& Moriyama, R. (1994). A spore-lytic enzyme released from Bacillus cereus spores during germination. Microbiology 140, 1403-1410.

Marquis, R. E., Sim, J. \& Shin, S. Y. (1994). Molecular mechanism of resistance to heat and oxidative damage. J Appl Bacteriol 76, 40-48.

Miyata, S., Moriyama, R., Sogimoto, K. \& Makino, S. (1995). Purification and partial characterization of a spore cortex-lytic enzyme of Clostridium perfringens S40 spores. Biosci Biotechnol Biochem 59, 514-515.

Moriyama, R., Kudoh, S., Miyata, S., Nonobe, S., Hattori, A. \& Makino, S. (1996). A germination-specific spore cortex enzyme from Bacillus cereus spores, cloning and sequencing of the gene and molecular characterization of the enzyme. J Bacteriol 178, 5330-5332.

Moriyama, R., Fukuoka, H., Miyata, S., Kudoh, S., Hattori, A., Kozuka, S., Yasuda, Y., Tochikubo, K. \& Makino, S. (1999). Expression of a germination-specific amidase, SleB, of bacilli in the forespore compartment of sporulating cells and its localization on the exterior side of the cortex in dormant spores. J Bacteriol 181, 2373-2378.

Nicholson, W. L., Munakata, N., Horneck, G., Melosh, H. J. \& Setlow, P. (2000). Resistance of Bacillus endospores to extreme terrestrial and extraterrestrial environments. Microbiol Mol Biol Rev 64, 548-572.
Oloyede, O. B. \& Scholefield, J. (1994). Inhibition of Bacillus spores by combinations of heat, potassium sorbate, $\mathrm{NaCl}$ and pH. World J Microbiol Biotechnol 10, 579-582.

Paidhungat, M. \& Setlow, P. (2000). Role of Ger proteins in nutrient and nonnutrient triggering of spore germination in Bacillus subtilis. J Bacteriol 182, 2513-2519.

Popham, D. L., Hanlin, J., Costello, C. E. \& Setlow, P. (1996). Muramic lactam in peptidoglycan of Bacillus subtilis spores is required for spore outgrowth but not for spore dehydration or heat resistance. Proc Natl Acad Sci U S A 93, 15405-15410.

Sekiguchi, J., Akeo, K., Yamamoto, H., Khasanov, F. K., Alonso, J. C. \& Kuroda, A. (1995). Nucleotide sequence and regulation of a new putative cell wall hydrolase gene, cwlD, which affects germination in Bacillus subtilis. J Bacteriol 177, 5582-5589.

Stewart, G. S. A. B., Johnstone, K., Hagelberg, E. \& Ellar, D. J. (1981). Commitment of bacterial spores to germinate. Biochem J 198, 101-106.

Warth, A. D. (1978). Molecular structure of the bacterial spore. Adv Microb Physiol 17, 1-47.

Warth, A. D. (1980). Heat stability of Bacillus cereus enzymes within spores and in extracts. J Bacteriol 143, 27-34.

Wax, R. \& Freese, E. (1968). Initiation of the germination of Bacillus subtilis spores by a combination of compounds in place of L-alanine. J Bacteriol 95, 433-438.

Received 6 June 2001; revised 13 July 2001; accepted 20 August 2001. 